\title{
Re-taking mastery of life: a story of a Chinese policeman
}

Algae Kit Yee Au

Correspondence:

algae.au@connect.polyu.hk Gambling Counseling Division, Kei Yam Family Services Centre, Hong Kong

\author{
Abstract \\ This story expands our understanding with regards to the high risk of problem \\ gambling on a policeman's life.
}

It was the summer of 2006. I was wandering on the street aimlessly. My thoughts jumped back and forth, from ending my useless life to robbing a bank. Either option could help me to clear my gambling debts, and put a stop to all the pain that my family and I myself had endured all those years. I was in my mid-thirties, the golden age of a man, with a stable job and a loving family, but everything had been ravaged by pathological gambling.

My relationship with gambling rooted in my childhood, when betting was regarded as an entertainment, and a normal family activity which would enhance communication. We played mahjong on holidays and weekends. My father was keen on horse racing. Sometimes he asked me to place the bets for him at a nearby off-course betting branch, long before I had reached the legal age to be admitted. I was delighted to be on his service, as I would be granted some money if he won, for my legwork or probably also for my luck. I was convinced that winning was simple, as a ten dollars bet could easily yield ten times reward. As a teen, I did gamble sometimes with my peers but I did not take gambling seriously. I simply viewed it as a leisure game. However, gambling finally became an integral part of my life when I joined the police force at eighteen after completing Form 5.

As a new comer to the police force, I was eager to socialize and adapt successfully to the new working environment. In the 1990's gambling among the policemen was nothing but an open secret. Gambling activities usually took place in the entertainment room inside the police station. After a few years soaking in the gambling sub-culture, I found myself being controlled by excessive gambling. I was betting on credits and loans. I started to overdraft from credit cards, and borrowed from financial companies. Borrowing money was not new to me. I used to accompanying my mother to borrow money from relatives since I was a child due to my dad's gambling problem. My bet was growing bigger, so was my debt.

Since the 1997 handover to China, gambling activities at the workplace was gradually banned. I shifted to gamble at the dazzling and glamorous casinos in Macau where I was treated like a king. My self-esteem, which was lost at the workplace due to a low rank and a poor education, was instantly regained at Macau casinos. At first I was

(c) 2013 Au; licensee Springer. This is an Open Access article distributed under the terms of the Creative Commons Attribution License (http://creativecommons.org/licenses/by/2.0), which permits unrestricted use, distribution, and reproduction in any medium, provided the original work is properly cited. 
going with a couple of colleagues, but later I was mostly on my own. Shift works provided the convenience for my gambling trip without drawing any suspicion from my wife. I was particularly interested in baccarat and sic bo. I did win up to hundreds of thousand a night but most of the time I lost. To chase losses, I borrowed money from the Macau loan sharks. The gambling debts snowballed till I finally asked my wife for help.

It was such a big shock to my wife when I broke the news. She could not believe that the loving husband she had been so proud of was in fact a liar and a gambling addict who was half-a-million in debt. Being determined to keep an intact family for our new born child, she bailed me out by seeking help from her maiden family. The gambling debts were cleared so quickly that I hardly had time to regret and feel the pain. Six months later, I resumed betting.

My gambling spree went on for another couple of years. My career was finally affected when letters from creditors and financial companies were faxed to my workplace. My superiors urged me to settle the things outside and promotion became impossible. News spread and colleagues simply looked down on me. I felt very stressful, frustrated and isolated. In 2005, I was knee-deep in the big muddy. I was half-a-million in debt again. My wife smelled something as I looked like a corpse and had no money to take home on the pay date. She knew I was in gambling problem again. Totally disappointed and fed up with my lies, rather than asking how much I owed, she asked for a divorce instead.

I thought of death, as a means to make up for what my family had suffered. I contacted the welfare officer to check how much fund my family would be able to get if I died. I was consoled to know that the money would be enough to cover my debts and possibly rear up my child. Wandering on the street all day tossing between the thoughts of killing myself or committing robbery, I finally went home. My wife took me to Kei Yam Church where I met Rev. Siu and many ex-gamblers. I told them my gambling problem. They cried with me and accepted who I was. They knew how I felt as they themselves had been gamblers before. I converted to Christ and was given a new life that afternoon.

God did not help me to clear the debts but He gave me the courage to face my problems, and to take responsibility to fix the problems. With the advice from Rev. Siu, I underwent financial restructuring with my debtors so I could pay with an affordable amount in each installment by extending the repayment plan. With a new life goal and the support given by my church friends, I was able to resist the temptation of gambling and finally hit the road to reformation. My wife, being impressed with my changes, finally decided to withdraw the divorce petition.

Now, I can proudly announce that I have cleared all the gambling debts with the credit cards issuing companies and the loan sharks. I am now dealing with the personal debts that I owed my friends and relatives, while rebuilding my relationships with them at the same time. Now, I am the leader of a Christian fellowship helping gamblers to achieve total abstinence. My wife has converted too. We love each other more than ever. She aspires to be the pianist of the fellowship and the church. We are so grateful to be given an opportunity to serve our church friends and the Lord. I understand that the road to recovery is never smooth, yet, I am confident that I shall be able to regain mastery of life with the support from my family, the recovered gamblers and the church. 
Competing interest

The author declares that she has no competing interest.

Authors' information

This true story was written by Algae Kit Yee Au, a volunteer at Gambling Counseling Division, Kei Yam Family Services Centre, Hong Kong.

Received: 2 February 2013 Accepted: 2 February 2013

Published: 12 March 2013

doi:10.1186/2195-3007-3-8

Cite this article as: Au: Re-taking mastery of life: a story of a Chinese policeman. Asian Journal of Gambling Issues and Public Health 2013 3:8.

Submit your manuscript to a SpringerOpen ${ }^{\odot}$ journal and benefit from:

- Convenient online submission

- Rigorous peer review

- Immediate publication on acceptance

- Open access: articles freely available online

- High visibility within the field

- Retaining the copyright to your article

Submit your next manuscript at $>$ springeropen.com 